\title{
Radiometric Assay for Direct Quantitation of Rat Liver Cytochrome P-450b Using Monoclonal Antibodies ${ }^{1}$
}

\author{
Charles E. Rothwell, M. B. Khazaeli, ${ }^{2}$ and Isadore A. Bernstein \\ Department of Environmental and Industrial Health, University of Michigan, Ann Arbor, Michigan 48109
}

Received February 4, 1985

\begin{abstract}
A simple and sensitive assay has been developed that is capable of detecting as little as 0.2 $\mathrm{ng}$ of the major isozyme of cytochrome P-450 (P-450b) isolated from the livers of phenobarbitalinduced rats. This assay employs monoclonal antibodies generated against cytochrome P-450b to directly quantify the levels of this enzyme in various tissues. Separation of bound from free labeled antibody is achieved by using 6,9-diaminoacridine lactate (Rivanol). The useful range of the assay is between 1 and $100 \mathrm{ng}$ of P-450b. @ 1985 Academic Press, Inc.

KEY WORDS: cytochrome P-450; monoclonal antibody; radiometric assay; Rivanol (acridines).
\end{abstract}

In the past 10 years the known isozymes of cytochrome P-450 have increased from two to dozens. P-450s have been shown to exist in almost every tissue of mammals and are found in plants and bacteria as well. These multiple isozymes of P-450 have been shown to exhibit a certain degree of structural homogeneity, but differences have been found between homologous isozymes from closely related species. To quantify levels of these isozymes of cytochrome P-450 in various tissues, or to identify structural differences between closely related forms, investigators have turned to highly sensitive immunochemical assay techniques, often utilizing highly specific monoclonal antibodies (MAb's). ${ }^{3}$

This laboratory has been developing a sensitive immunochemical assay for the dif-

\footnotetext{
' Submitted to the Horace Rackham School of Graduate Studies at the University of Michigan in partial fulfillment of the requirements for the $\mathrm{PhD}$ degree (C.E.R.).

${ }^{2}$ Present address: University of Alabama in Birmingham, University Station, 222 Tumor Institute, Birmingham, Ala. 35294.

${ }^{3}$ Abbreviations used: MAb, monoclonal antibody; PBS, phosphate-buffered saline; BSA, bovine serum albumin; PB, phenobarbital; NSB, nonspecific binding.
}

ferent isozymes of cytochrome P-450 which would be useful clinically. The assay being developed utilizes monoclonal antibodies. The standard radioimmunoassay did not work well with our monoclonal antibodies because of the insolubility of the labeled $P$ 450 (1). A search of the literature for an alternative approach uncovered an article by Al-Shawi et al. (2) which led to the idea of using labeled antibody and Rivanol (6,9diaminoacridine lactate) to separate bound from free fractions in a radiometric assay system. These authors reported that this reagent precipitates the antibody-antigen complex while leaving the unbound antibody in solution.

\section{MATERIALS AND METHODS}

Rivanol (purity: 97-100\%) was purchased from the Sigma Chemical Company. Purified rabbit P-450s (LM2, LM3a, LM3b, LM3c, LM4, and LM6) as well as phenobarbital (PB)-induced rabbit liver microsomes were generous gifts from Dr. Minor J. Coon, Department of Biological Chemistry, University of Michigan. Rat liver microsomes and cytochrome P-450c were prepared by the method of Ryan et al. (3). Mitochondria 
were prepared from rat liver by the method of Mitra and Bernstein (4). All of the rats used in these studies were of a CFN strain (Carsworth Farms) and were obtained from a randomly inbred colony maintained for over 15 years at the University of Michigan School of Public Health.

Cytochrome P-450b was purified from the livers of PB-induced rats by the method of West et al. (5). The P-450b used in these experiments had a specific content of 16 $\mathrm{nmol} / \mathrm{mg}$ protein (1) and was shown to be purified to apparent homogeneity by the polyacrylamide gel electrophoresis technique of Laemmli (6). All protein measurements were made using the method of Lowry et al. (7).

Monoclonal antibodies were generated against the $\mathrm{P}-450 \mathrm{~b}$ antigen by the method previously described by Khazaeli et al. (8). Briefly, each of five female Balb/c mice was given an injection of $10 \mu \mathrm{g}$ of P-450b ip emulsified in Freund's complete adjuvant. The primary immunization was followed by two secondary immunizations in Freund's incomplete adjuvant at 3-week intervals. Serum was collected 1 week after the final injection and tested for anti-P-450b titer via enzyme-linked immunosorbant assay (ELISA). The mouse with the highest titer was then given injections of antigen $(10 \mu \mathrm{g}$ each site) ip and iv in phosphate-buffered saline (PBS) 3 days prior to the fusion. On the day of the fusion; the mouse was sacrificed, its spleen was removed, and lymphocytes isolated from the spleen were fused with cells of a nonsecreting myeloma cell line (X63-Ag8.653) by centrifugation in the presence of $15.6 \%$ polyethylene glycol 4000 . Hybridoma 6C9 produced antibodies that reacted against the $\mathrm{P}-450 \mathrm{~b}$ antigen, but showed no cross-reactivity for the P-450 species LM2, LM3a, LM3b, LM3c, LM4, and LM6 derived from the liver of the rabbit; or P-450c from the rat when tested via ELISA (1). Antibodies from the 6C9.3 subclone (IGG1 subclass) were purified by the method of Ey et al. (9) and labeled with iodine-125 $\left({ }^{125} \mathrm{I}\right)$ by the method of Hunter and Green- wood (10). For these experiments, $4 \mu \mathrm{g}$ of protein was reacted with $1.0 \mathrm{mCi}$ of ${ }^{125} \mathrm{I}$ yielding labeled MAb's with a specific activity of approximately $40 \mu \mathrm{Ci} / \mu \mathrm{g}$ protein. The labeled antibodies were stored at $4^{\circ} \mathrm{C}$ in PBS containing $1 \%$ bovine serum albumin (BSA).

The Rivanol Assay. Tissue samples to be assayed were diluted with $100 \mathrm{mM}$ potassium phosphate buffer ( $\mathrm{pH}$ 7.4) containing $30 \%$ glycerol, $1 \mathrm{mM}$ ethylenediaminetetraacetic acid, and $0.3 \%$ sodium cholate to a concentration of $1 \mathrm{mg}$ protein $/ \mathrm{ml}$. The diluted samples were allowed to incubate for at least $20 \mathrm{~min}$ at room temperature with gentle mechanical shaking to ensure solubilization of P-450b. Pure P-450b standards were treated identically except that they were diluted to a protein concentration of $0.1 \mathrm{mg} / \mathrm{ml}$ in the solubilizing buffer. After solubilization, both samples and standards were diluted as necessary with PBS containing 1\% BSA. Standards and samples were prepared fresh for each assay because loss of binding activity was noted if they were allowed to sit in the solubilizing buffer for longer than a couple of days.

The stock ${ }^{125}$ I-labeled MAb's were diluted to approximately $60,000 \mathrm{cpm} / 150 \mu \mathrm{l}$ with PBS containing $1 \%$ BSA immediately before use. The reaction was started by adding 150 $\mu \mathrm{l}$ of the labeled antibodies to $100 \mu \mathrm{l}$ of the sample in $12 \times 75$ disposible glass tubes. After overnight incubation at room temperature with gentle shaking, $2 \mathrm{ml}$ of $0.05 \%$ Rivanol in $10 \mathrm{mM}$ sodium phosphate buffer (pH 7.4) was added to each tube. Sodium chloride was not added to this solution because this salt will pecipitate the Rivanol. The tubes were mixed lightly using a Vortex mixer, allowed to stand at room temperature for $30 \mathrm{~min}$, and then centrifuged at $1000 \mathrm{~g}$ for $15 \mathrm{~min}$ at $15^{\circ} \mathrm{C}$ in an IEC Model PR-J refrigerated centrifuge. The $\mathrm{P}-450 \mathrm{~b}-\mathrm{MAb}$ complex formed a tight, bright-yellow pellet while the unbound MAb remained in solution. The supernatant solutions were aspirated and the tubes were counted for $1 \mathrm{~min}$ in a Micromedic 4-200 Plus $\gamma$ counter. Washing the pellet did not significantly reduce the 
background counts, and was not done routinely.

\section{RESULTS}

Figure 1 shows a typical standard curve generated by this radiometric assay. Each point shown represents the mean of triplicate analyses. The standard deviation for each point was less than $1 \%$ of the mean in all standard curves run by this method. When standard curves were generated using P-450b that had not been solubilized with cholate, the sensitivity of the assay was decreased 50fold. The increased sensitivity of the standards using cholate-solubilized $\mathrm{P}-450 \mathrm{~b}$ is presumably due to exposure of more antigenic binding sites that occurs with the disruption of large P-450 polymers by the detergent. Because the way in which the standards and samples are diluted results in a constant detergent-to-protein ratio and not a constant detergent concentration for all samples, it seems that the former is more important in generating the curves obtained. As can be seen in Fig. 1, as little as $0.2 \mathrm{ng}$ of pure P. $450 \mathrm{~b}$ could be detected by this assay, with a useful range between 1 and $100 \mathrm{ng}$ of protein.

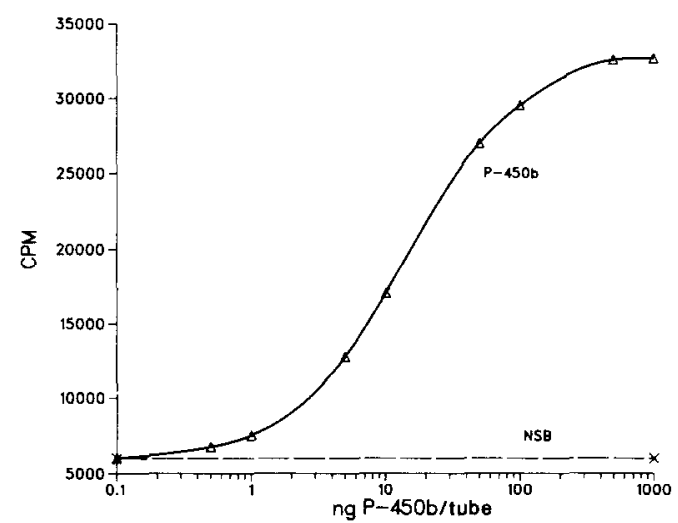

FiG. 1. Standard curve obtained when $100 \mu \mathrm{l}$ cold cytochrome P-450b is incubated with $150 \mu{ }^{125}$ I-labeled 6C9.4 MAb's and $2 \mathrm{ml}$ of $0.05 \%$ Rivanol is employed to separate bound from free fractions as described under Materials and Methods. Total radioactivity added to each tube for this particular assay was $47,200 \mathrm{cpm}$. The line labeled NSB indicates no change in nonspecific binding whether no protein was present or $1000 \mathrm{ng}$ of PB-induced rabbit liver microsomes was present.
Approximately $80 \%$ of all binding occurred in the first hour of incubation (Fig. 2), and binding was essentially complete by 8 hours. The nonspecific binding (NSB), about $12 \%$ of the total counts, did not increase with increased incubation time. This binding was not greatly reduced by washing the pellet, or by precoating the tubes with either BSA or silicon (data not shown). Therefore, this additional wash was not routinely done.

Table 1 gives an indication of the levels of cytochrome P-450b that were found in microsomes and mitochondria from both PBinduced and noninduced rats. When the Rivanol radiometric assay was used, the results indicated that, for rat liver, there was no detectable $\mathrm{P}-450 \mathrm{~b}$ in noninduced microsomes whereas P-450b comprised $11 \%$ of all microsomal protein in PB-induced animals. Similar values were generated in three separate experiments using different rats of the same strain. These findings agree with data presented by Pickett $e t$ al. (11) using another immunochemical technique (Table 1). Both assay techniques indicated that cytochrome $\mathrm{P}-450 \mathrm{~b}$ levels were not measurable in noninduced rat liver microsomes, whereas $\mathbf{P}$ $450 \mathrm{~b}$ was shown to comprise about $10 \%$ of all microsomal protein in the livers of PBinduced rats. One big difference between these two different techniques is that the rocket immunoelectrophoresis technique as performed by Pickett et al. required 1000fold more microsomes and standard to generate linear curves than did the Rivanol assay. Total P-450 content of the liver microsomes of both induced and noninduced rats as measured by the difference spectrum technique of Omura and Sato (12) were similar for both studies (Table 1). This method did indicate that induction of total P-450 content had occurred due to PB treatment, but grossly underestimates the extent of induction of the $\mathrm{P}-450 \mathrm{~b}$ isozyme.

In an additional experiment, mitochondria isolated from the livers of these rats were assayed for P-450b content by the Rivanol assay and it was shown that $3 \%$ of the total 


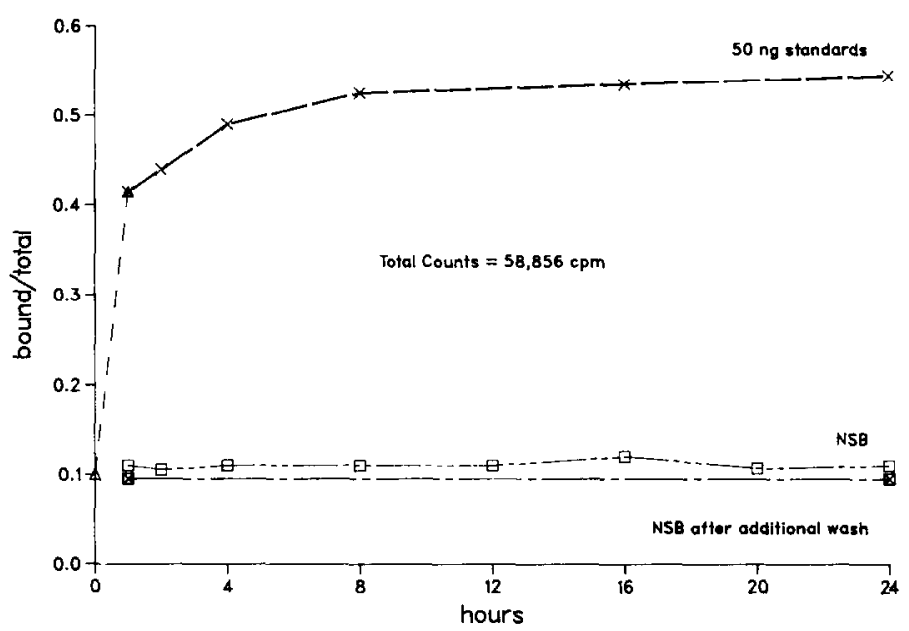

FIG. 2. Time-related binding of P-450b and ${ }^{125}$ I-labeled 6C9.4 MAb's when assayed as described under Materials and Methods. Each point is the mean of data on duplicate tubes. Nonspecific binding was measured in tubes that contained no protein other than that of the MAb solutions. Washing the pellet with PBS resulted in very little decrease in background counts.

mitochondrial protein was P-450b in the PBinduced rats whereas no $P-450 \mathrm{~b}$ was detected in the mitochondria from noninduced rat liver. It is possible that the P-450b detected in the mitochondrial fraction may actually be a different isozyme of $P-450$ sharing similar antigenic sites with microsomal P-450b even though the 6C9 Mabs used in the assay showed no cross-reactivity with any P-450 species tested except the rat P-450b.

TABLE I

QUANTITATION OF P-450b IN RAT MICROSOMES AND MITOCHONDRIA

\begin{tabular}{cccc}
\hline Sample (ng) & cpm + SD & \% Total protein & P-450 content $^{a}$ \\
\hline Nonspecific binding & $8042+320$ & & \\
Liver microsomes & & $0(\mathrm{ND})^{b}$ & 0.94 \\
1000 noninduced & $8600+266$ & 0 & $(1.08)^{c}$ \\
500 noninduced & $7992+72$ & 0 & 2.43 \\
100 noninduced & $7852+68$ & $11(8.9)^{b}$ & $(2.58)^{c}$ \\
100 PB induced & $18,832+76$ & 11 & 0.24 \\
50 PB induced & $14,676+125$ & & 0.64 \\
10 PB induced & $9701+58$ & 0 & 3 \\
Mitochondria & & $3546+687$ & 0.25 \\
1000 noninduced & $25,230+259$ & & \\
1000 PB induced & &
\end{tabular}

\footnotetext{
${ }^{a}$ P-450 specific contents were measured by the method of Omura and Sato (12) and are expressed as nmol P$450 / \mathrm{mg}$ protein. All tissue samples were solubilized and assayed as described under Materials and Methods. All samples were done in duplicate.

${ }^{b}$ These values were generated by the rocket immunoelectrophoresis technique of Pickett et al. (11) using rabbit polyclonal antibodies directed against cytochrome P-450b, and liver microsomes from immature Long-Evans rats. For noninduced rat liver microsomes the area under the peaks could not be determined (ND).

${ }^{c}$ Values reported by Pickett et al. (11) for the same animals mentioned above.
} 


\section{DISCUSSION}

An ideal assay for routine use should be accurate, sensitive, reproducible, and easy to perform. It should also yield results quickly, with a minimum of expense, and require only materials that are common to a wellequipped biological laboratory. The radiometric assay presented here displays all the characteristics mentioned above. All determinations made by this assay were in agreement with values reported by other laboratories, and were consistent from assay to assay. Duplicate samples never varied by more than $50 \mathrm{cpm}$ (i.e. $<1 \%$ of sample counts) for the points of the standard curve, even though the sample counts were between 8000 and $35,000 \mathrm{cpm}$. Tissue samples showed more variation, but standard deviations were always less than $8 \%$ of the mean for any given point. The assay could detect as little as $0.2 \mathrm{ng}$ of pure P-450b. For a molecule whose molecular weight is in the 100,000 range, this is a detection limit of $2 \times 10^{-16}$ mol. There have been other recent reports of specific radioimmunoassays of cytochrome P-450 using iodinated cytochrome P-450 and polyclonal antibodies $(13,14)$, but their sensitivities do not appear to be as great as those reported here. Also, these other assays do not employ monoclonal antibodies.

Binding was rapid, reaching $90 \%$ of the equilibrium value by $4 \mathrm{~h}$. Rivanol is quite inexpensive, as are all buffers and reagents with the exception of the antigen and the labeled MAb. The ${ }^{125}$ I-labeled MAb's were very stable when stored as indicated in METHODS. All of the assays represented here were performed over a 1 -month period with the same lot of iodinated antibodies, with no noticeable loss of binding activity. Another advantage of this assay is that the addition of large amounts of extraneous protein, lipid, etc. does not interfere with binding of the antibody to the antigen.

One disadvantage of this radiometric assay is that iodination may destroy the binding capacity of an antibody. Several MAb's directed against rat liver cytochrome $\mathrm{P}-450 \mathrm{c}$ have been iodinated in this laboratory and were found to be inactive with respect to binding to the antigen after iodination (data not shown). Still, the advantages of sensitivity, reproducibility, low cost, ease, and quickness that this assay offers should make it advantageous for quantifying any P-450 isozyme for which the iodinated monoclonal antibody remains active.

\section{ACKNOWLEDGMENTS}

The authors would like to thank Gayle Jackson for her efforts in iodinating the antibodies used in this work. This work was supported by a grant from the National Institutes of Health, Public Health Service (5 R01 AM 15206) and by a gift from Gelman Sciences Inc., Ann Arbor, Michigan.

\section{REFERENCES}

1. Rothwell, C. E. (1984) PhD Thesis, Univ. of Michigan, Ann Arbor.

2. Al-Shawi, A., Mohammed-Ali, S., Houts, T., Hodgkinson, S., Nargessi, R. D., and Landon, J. (1981) Ligand Quart. 4(4), 43-51.

3. Ryan, D., Lu, A. Y. H., and Levin, W. (1978) in Methods in Enzymology (Fleischer, S., and Packer, L., eds.), Vol. 52, Part C, pp. 117-123, Academic Press, New York.

4. Mitra, R. S., and Bernstein. I. A. (1970) J. Biol Chem. 245(6), 1255-1260.

5. West, S. B., Huang, M., Miwa, G. T., and Lu, A. Y. H. (1979) Arch. Biochem. Biophys. 193(1), $42-50$.

6. Laemmli, U. K. (1970) Nature (London) 227, 680685.

7. Lowry, O. H., Rosebrough, N. J., Farr, A. L., and Randall, R. J. (1951) J. Biol. Chem. 193, 265275.

8. Khazaeli, M. B., England, B. G., Dieterle, R. C., Nordblum. G. A., Kabza, G. A., and Beierwaltes, W. H. (1981) Endocrinology 109(4), 1290-1292.

9. Ey, P. L., Prowse, S. J., and Jenkin, C. R. (1978) Immunochemistry 15, 429-436.

10. Hunter, W. M., and Greenwood, F. C. (1962) Nature (London) 194, 495.

11. Pickett, C. B., Jeter, R. L., Morin, J., and Lu, A. Y. H. (1981) J. Biol. Chem. 256(16), 88158820.

12. Omura, T., and Sato, R. (1964) J. Biol. Chem. 239, 2370.

13. Phillips, I. R., Shepard, L. D.., Bayney, R. M., Pike, S. F., Rabin, B. R., Heath, R., and Carter, N. (1983) Biochem. J. 212, 55-64.

14. Luster, M. L., Lawson, M. D., Linko, P., and Goldstein, J. A. (1983) Mol. Pharmacol. 23, 252257. 